\title{
DHIKR (RECITATION) AND RELAXATION IMPROVE STRESS PERCEPTION AND REDUCE BLOOD CORTISOL LEVEL IN TYPE 2 DIABETES MELLITUS PATIENTS WITH ADM
}

\author{
Faisal Amir ${ }^{1}$, Gondo Mastutik ${ }^{2}$, M. Hasinuddin ${ }^{3}$, Suhartono Taat Putra ${ }^{2}$ \\ ${ }^{1}$ Master Program on Basic Medical Science, ${ }^{2}$ Department of Anatomic Pathology, Faculty of Medicine, Universitas \\ Airlangga, Surabaya, ${ }^{3}$ College of Health Science Ngudia Husada Madura, Indonesia
}

\section{ABSTRACT}

\begin{abstract}
Recitation and relaxation are translated as stimuli that can turn distress (uneven conditions) into eustress (balanced conditions). The purpose of this study was to explain the effect of recitation and relaxation on improving stress perception and decreasing blood cortisol levels in patients with type 2 diabetes mellitus with Antidiabetic Medication (ADM). This was a quasi-experimental study with non randomized control group pretest posttest design. The population in this study were all type 2 diabetes mellitus patients at the Internal Medicine Clinic of Syarifah Ambami Rato Ebu Hospital, Bangkalan. The study sample was divided into 2 groups, control and intervention, each of which comprised 14 respondents. First, the respondents were asked to fill in an informed consent form and identity, and fill in the Depression Anciety Stress Scale 42 questionnaire (DASS 42) and their cortisol levels were examined as pre-treatment data. Furthermore, for 6 weeks the intervention group was given with recitation and relaxation treatment, while the control group was only given with health education. After 6 weeks, the second group respondents were asked to fill in DASS 42 and the cortisol levels as data after treatment were examined. Different data before and after treatment were tested for normality using Shapiro-Wilk and normal data distribution were obtained so that the different tests used independent T test with a $=0.05$. Recitation and relaxation may significantly improved stress perception with $p$ value $(0.001)<0.05$ and reduce cortisol levels with $p$ value (0.024) $<0.05$. Recitation and relaxation improved stress perception so that the hypothalamic pituitary adrenal (HPA) axis produced a balanced level of the hormone cortisol. Cortisol in a balanced level may improve various metabolic processes.
\end{abstract}

Keywords: Recitation; relaxation; perception of stress; cortisol; type 2 DM

\section{ABSTRAK}

Zikir dan relaksasi diterjemahkan sebagai stimulus yang mampu mengubah distress (kondisi tidak seimbang) menjadi eustress (kondisi seimbang). Tujuan penelitian ini adalah untuk menjelaskan pengaruh zikir dan relaksasi terhadap perbaikan persepsi stres dan penurunan kadar kortisol darah pada pasien diabetes mellitus tipe 2 dengan Obat Anti Diabetes (OAD). Jenis penelitian adalah quasi eksperimen dengan the non randomized control group pretest postest design. Populasi dalam penelitian ini adalah seluruh pasien diabetes mellitus tipe 2 di Poli Interna RSUD Syarifah Ambami Rato Ebu Bangkalan. Sampel penelitian dibagi menjadi 2 kelompok yaitu kontrol dan intervensi yang masing-masing berjumlah 14 responden. Pertama responden diminta mengisi lembar informed consent, identitas, mengisi quesioner Depresion Anciety Stress Scale 42 (DASS 42) dan diperiksa kadar kortisol sebagai data sebelum perlakuan. Kemudian selama 6 minggu kelompok intervensi diberikan perlakuan zikir dan relaksasi, sedangkan kelompok kontrol hanya diberikan health education. Setelah 6 minggu responden kedua kelompok diminta mengisi DASS 42 dan diperiksa kadar kortisol sebagai data setelah perlakuan. Data selisih sebelum dan setelah perlakuan dilakukan uji normalitas menggunakan Shapiro-Wilk dan didapatkan distribusi data normal sehingga uji beda menggunakan independent $T$ test dengan a = 0,05. Zikir dan relaksasi secara signifikan dapat memperbaiki persepsi stres dengan p value $(0,001)<0.05$ dan menurunkan kadar kortisol dengan $p$ value $(0,024)<0.05$. Zikir dan relaksasi memperbaiki persepsi stres sehingga hypothalamic pituitary adrenal (HPA) axis menghasilkan hormon kortisol dalam kadar seimbang. Kortisol dalam kadar yang seimbang akan memperbaiki berbagai proses metabolisme tubuh.

Kata kunci: Zikir; relaksasi; persepsi stres; kortisol; DM tipe 2

Correspondence: Faisal Amir, Master Program on Basic Medical Science, Faculty of Medicine, Universitas Airlangga, Surabaya, Indonesia. E-mail:

pISSN:2355-8393 • eISSN: 2599-056x • doi: http://dx.doi.org/10.20473/fmi.v54i4.10707

- Fol Med Indones. 2018;54:249-255 • Received 30 Aug 2017 • Accepted 22 Feb 2018

- Open access under CC-BY-NC-SA license • Available at https://e-journal.unair.ac.id/FMI/ 


\section{INTRODUCTION}

A decrease in blood glucose levels is found in patients with type 2 diabetes mellitus with anti-diabetic drugs (ADM) who perform recitation and relaxation. Diabetes mellitus is not a single disease entity, but is a collection of metabolic disorders that have similar background to hyperglycemia. Hyperglycemia in diabetes mellitus is caused by defects in insulin secretion, insulin action or more often both (Kumar et al 2013).

The prevalence of diabetes mellitus in Indonesia according to the International Diabetes Federation (IDF) is estimated at $4.6 \%$ of the 125 million population, which is around 5.6 million in 2000. It is estimated that in 2020 there will be around 8.2 million people with diabetes mellitus (Soegondo 2009). East Java Province shows the number of 605,975 people over the age of 15 years suffering from diabetes mellitus (Ministry of Health of Republic of Indonesia 2014). The report center for data and information processing at Syarifah Ambami Rato Ebu Hospital, Bangkalan noted that there were around 608 patients diagnosed with type 2 diabetes mellitus in 2016.

Diabetes mellitus patients must avoid physical and psychological distress. This is because negative stress (distress) will increase blood glucose levels, especially in patients with diabetes mellitus. Dabbar-McEwen (2001) stated that stress consists of stress perception and stress response. Psychological stress perceptions are interpreted as learning processes to select, organize, and interpret stress correctly. Whereas, the stress response is more biological. It involves the hypothalamic pituitary adrenal (HPA) axis and autonomic nervous system (ANS) (Putra 2011). According to Selye (1936), stage 2 or resistant stress causes the hypothalamus to release corticotropin releasing hormone (CRH). CRH stimulates the anterior pituitary to secrete adrenocorticotropin hormone (ACTH), then to the adrenal cortex and increase cortisol secretion (Tortora \& Derrickson 2009). Cortisol stimulates gluconeogenesis, lipolysis and proteolysis (Sherwood 2011). Costisol has biochemical effects on the endocrine, nervous and immune systems (Blauer-Wu 2002 in Lorentz 2006). Prolonged exposure to high cortisol levels causes energy waste in muscles, suppression of immune system, gastrointestinal ulceration, and pancreatic beta cell failure (Tortora \& Derrickson 2009).

Recitation and relaxation function as mind body therapy triggers positive stress perception (Lorentz 2006). Positive perceptions can be formed by strengthening realistic expectations for healing, ability of taking lessons, and determination (Nursalam 2007). Recitation and relaxation can calm the soul and improve the perception of stress so that the HPA Axis as a stress response pathway becomes balanced in secreting cortisol. A balanced cortisol level controlled can reduce blood glucose levels and hemoglobin A1c ( $\mathrm{HbA} 1 \mathrm{c})$. It has been proven that recitation is more effective in lowering blood glucose levels than benson relaxation (Yanti 2012). Recitation can be performed jahr (clear pronunciation), qalbi or sir (contemplation in the heart), ruh (recitation of all souls without body count), and fi'liy (recitation through deeds) (Amin \& Al-Fandi 2008). This study emphasized more on the use of jahr recitation combined with deep breathing relaxation. The purpose of this study was to explain the effect of recitation and relaxation on the improvement of stress perception accompanied by the decrease in cortisol levels in type 2 diabetes mellitus patients with ADM.

\section{MATERIALS AND METHODS}

This was a quasi-experimental study with the non randomized control group pretest posttest design. The population was type 2 diabetes mellitus patients at the Internal Medicine Clinic of Syarifah Ambami Rato Ebu Hospital, Bangkalan, Madura in March 2017. The population was 40 persons and those who met the inclusion criteria were 28 people. The study sample was 14 people in control and intervention groups. First, respondents were asked to fill in the informed consent form, identity, and questionnaire of the Anxiety Stress Scale 42 (DASS 42), and he blood was taken to examine cortisol levels at 06.00-07.00 Western Indonesian Time as pre-treatment data. Then the intervention group was given with recitation and relaxation treatment with a duration of 10-15 minutes every morning, evening and at bedtime for 6 weeks. The control group was only given with health education. Every week a home visit was made at least once to each respondent. After 6 weeks the second group respondents were asked to fill in DASS 42 and cortisol levels were examined as data after treatment. The results of the research data before and after treatment were then reduced so that the delta values were obtained between the control and intervention groups. The delta value was then tested for data normality using Shapiro-Wilk. Data were said to be normally distributed if the value of $p>a$ (0.05). Whereas, the comparative test between the control and intervention groups used independent $\mathrm{T}$ test with a value of $=0.05$.

\section{RESULTS}

The results of the research data between before and after recitation and relaxation and univariate analysis and bivariate analysis were presented in the form of tables 
and figures. Table 1 shows the distribution of respondents based on sex, education levels and age of respondents.

Table 1 shows that almost all (78.6\%) respondents were female (11/14). The respondents $(42.9 \%)$ of the intervention group aged between 50-60 years (6/14), while $5 / 14(35.7 \%)$ of the control group aged between 50-60 years and over 60 years. The education levels of $6 / 14(42.9 \%)$ of the respondents from both groups was high education and $5 / 14(35.7 \%)$ of the respondents of both groups went to senior high school.

Fig. 1 shows the mean value of stress perception before and after recitation and relaxation treatment. Decreased mean values indicated an improvement in stress perception. Fig. 1 shows that the intervention group given with recitation and relaxation experience an improvement in stress perception which is marked by a decrease in the average DASS 42 value from 23.43 to 15.57. The control group did not experience an improvement in stress perception characterized by an increase in the mean DASS value 42 from 16.71 to 23.43 .

Table 2 shows the results of data normality test before and after recitation and relaxation (delta) treatment on stress perception using Shapiro-Wilk with $\mathrm{p}$ value $>0.05$. These results indicated that the delta values of stress perception in both groups were normally distributed.

Table 1. Distribution of respondents by sex, education levels and age in control and intervention groups

\begin{tabular}{lccccc}
\hline \multirow{2}{*}{ Respondents' characteristics } & \multicolumn{2}{c}{ Intervention } & \multicolumn{2}{c}{ Control } & Total \\
\cline { 2 - 5 } & $\mathrm{n}$ & $\%$ & $\mathrm{n}$ & $\%$ & $\mathrm{n}(\%)$ \\
\hline Sex & 3 & $21.4 \%$ & 3 & $21.4 \%$ & $6(21.4 \%)$ \\
$\quad$ Male & 11 & $78.6 \%$ & 11 & $78.6 \%$ & $22(78.6 \%)$ \\
$\quad$ Female & & & & & \\
\hline Age & 0 & $0 \%$ & 0 & $0 \%$ & $0(0 \%)$ \\
$\quad<40$ years & 3 & $21.4 \%$ & 4 & $28.6 \%$ & $7(25 \%)$ \\
$41-50$ years & 6 & $42.9 \%$ & 5 & $35.7 \%$ & $11(39.3 \%)$ \\
$51-60$ years & 5 & $35.7 \%$ & 5 & $35.7 \%$ & $10(35.7 \%)$ \\
$>60$ years & & & & & \\
Education levels & 2 & $14.3 \%$ & 3 & $21.4 \%$ & $5(17.9 \%)$ \\
Elementary school & 1 & $7.1 \%$ & 0 & $0 \%$ & $1(3.7 \%)$ \\
Junior high school & 5 & $35.7 \%$ & 5 & $35.7 \%$ & $10(35.7 \%)$ \\
Senior high school & 6 & $42.9 \%$ & 6 & $42.9 \%$ & $12(42.9 \%)$ \\
$\quad$ Bachelor degree & & & & \\
\hline
\end{tabular}

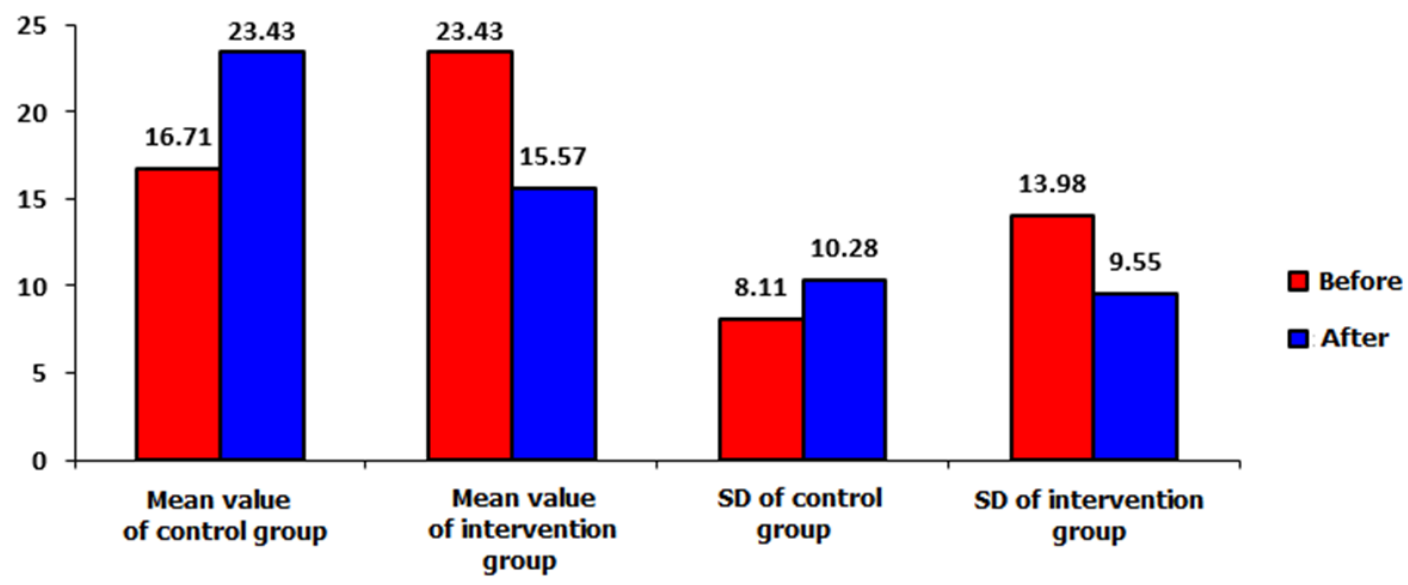

Fig. 1. Mean value of stress perception before and after recitation of recitation and relaxation in control and intervention group. 
Table 2. Results of normality data of comparative test (delta) improvement of stress perception before and after recitation treatment and relaxation in control and intervention groups

\begin{tabular}{clcccccc}
\hline \multirow{2}{*}{ Variable } & \multirow{2}{*}{ Groups } & \multicolumn{2}{c}{ Kolmogorov-Smirnov $^{\mathrm{a}}$} & \multicolumn{3}{c}{ Shapiro-Wilk } \\
& & Statistics & $\mathrm{df}$ & Sig & Statistics & df & Sig \\
\hline \multirow{2}{*}{ Stress level } & Intervention & 0.195 & 14 & 0.156 & 0.913 & 14 & 0.172 \\
\cline { 2 - 8 } & Control & 0.146 & 14 & 0.200 & 0.927 & 14 & 0.278 \\
\hline
\end{tabular}

Table 3. Difference test results (delta) of stress perception improvement before and after recitation treatment and relaxation in control and intervention groups

\begin{tabular}{ccccccc}
\hline Variable & Statistic test & Groups & $\mathrm{N}$ & $\begin{array}{c}\text { Mean } \\
\text { delta }\end{array}$ & $\begin{array}{c}\mathrm{p} \\
\text { Value }\end{array}$ & Conclusion \\
\hline \multirow{2}{*}{ Stress } & $\begin{array}{c}\text { Independent } \\
\text { T Test }\end{array}$ & $\begin{array}{c}\text { Intervention } \\
\text { Control }\end{array}$ & 14 & 7.86 & 0.001 & Significant \\
\hline
\end{tabular}

Table 3 shows the results of comparative test using independent $\mathrm{T}$ test with $\mathrm{p}$ value $(0.001)<0.05$. This means that there were significant differences in the improvement of stress perception between control group and intervention group after recitation and relaxation treatment.

Fig. 2 shows that the control group experiences an increase in cortisol mean value from $10.45 \mu \mathrm{g} / \mathrm{dl}$ to $14.91 \mu \mathrm{g} / \mathrm{dl}$. The intervention group also experienced an increase in cortisol mean value from $13.53 \mu \mathrm{g} / \mathrm{dl}$ to $13.85 \mu \mathrm{g} / \mathrm{dl}$.

Table 4 shows the results of the data normality test (delta) using Shapiro-Wilk with p value $>0.05$, meaning that the delta value of stress perception in both groups of data was normally distributed.

\section{DISCUSSION}

The results showed a significant difference in the improvement of stress perception between the control and intervention groups with $p$ value $(0.001)<0.05$. The difference in mean value of stress perception in the intervention group was higher than that in control group, which indicated an improvement in stress perception after being given recitation and relaxation.

Diabetes mellitus patients have a tendency to experience stress due to various factors. Research in diabetes mellitus patients in Karachi, Pakistan, concluded that most patients with type 2 diabetes mellitus experience anxiety (Khuwaja et al 2010). Physiological stress can lead to hyperglycemia and trigger diabetic ketoacidosis (DKA) and Hyperosmolar Hyperglycemic Nonketotic Syndrome (HHNS), while psychological stress negatively affects diabetes control (Smeltzer and Bare 2009).
The study of Ciechanowski et al (2005) provides evidence that the severity of symptoms of stress or depression is associated with poor diet control, adherence to medical therapy, functional impairment and increased treatment costs. Gaugler et al (2004) in Potter \& Perry (2009) stated that adjustments to treatment uncertainty and chronic diseases, such as obesity, hypertension, diabetes, asthma, and coronary artery disease cause situational stress at all age levels, especially the elderly.

Both groups of respondents could experience a reduction in stress, one of them because $6 / 14$ (42.9\%) of the education level of respondents were tertiary institutions and 5/14 (35.7\%) high school. This made it easy for researchers to guide recitation and relaxation and included positive perceptions, especially in the intervention group. A high level of education makes it easy for someone to absorb information and understand what is being experienced so that the perception of stress becomes more positive. Individuals with higher education level will usually have more knowledge and awareness in maintaining health (Irawan 2010).

Recitation and relaxation as mind body therapy is an application of psychotherapy that underlies the principle of holistic balance so that it can improve stress perception. Neuman (1972) stated that the reduction in stress is the goal of the nursing model system, while Roy (1980) mentioned that the goal of nursing is to help individuals for adaptation during healthy and illness (in Potter \& Perry 2009). Dhabhar-McEwen proposed the concept of stress that accommodates internal mental events according to Skinner or learning process according to Ader or cognition process according to Weiten (2004) which is called stress-perception (in Putra 2011). 


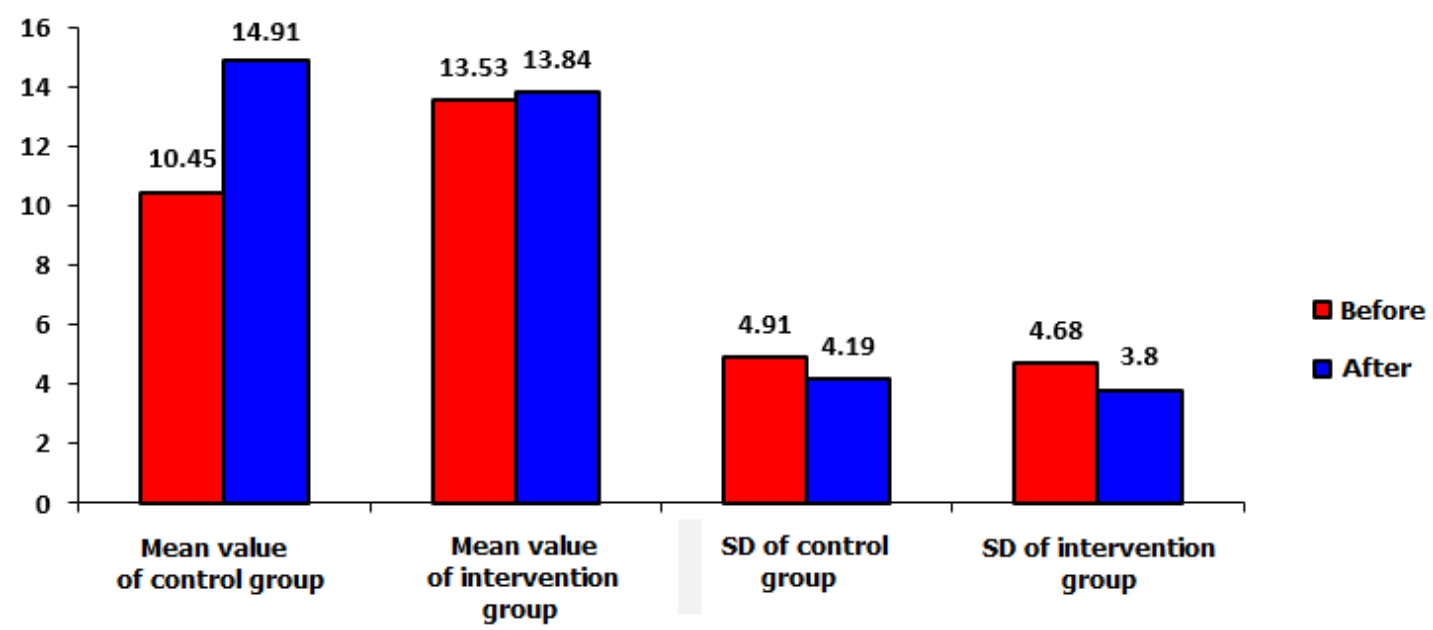

Fig. 2. Mean value of cortisol levels before and after recitation and relaxation in control and intervention groups.

Table 4. Results of data normality test (delta) of blood cortisol levels before and after recitation and relaxation therapy in control and intervention groups

\begin{tabular}{clcccccc}
\hline \multirow{2}{*}{ Variable } & \multirow{2}{*}{ Groups } & \multicolumn{2}{c}{ Kolmogorov-Smirnov $^{\mathrm{a}}$} & \multicolumn{3}{c}{ Shapiro-Wilk } \\
& & Statistics & Df & Sig & Statistics & df & Sig \\
\hline \multirow{2}{*}{ Cortisol } & Intervention & 0.121 & 14 & 0.200 & 0.934 & 14 & 0.347 \\
\cline { 2 - 8 } & Control & 0.105 & 14 & 0.200 & 0.970 & 14 & 0.873 \\
\hline
\end{tabular}

Table 5. Results of different tests (delta) of cortisol levels between control and intervention group after recitation and relaxation therapy

\begin{tabular}{ccccccc}
\hline Variable & Statistic test & Groups & $\mathrm{n}$ & $\begin{array}{c}\text { Mean } \\
\text { delta }\end{array}$ & $\begin{array}{c}\mathrm{p} \\
\text { value }\end{array}$ & Conclusion \\
\hline \multirow{2}{*}{ Cortisol } & $\begin{array}{c}\text { Independent } \\
\text { T Test }\end{array}$ & $\begin{array}{c}\text { Intervention } \\
\text { Control }\end{array}$ & 14 & 0.3214 & 0.024 & Significant \\
\hline
\end{tabular}

Recitation and relaxation, reading al-Quran, and prayer are religious therapies that can improve stress perception. Tahajud prayer with deep and earnest, solemn, precise, sincere, and continuous appreciation can foster constructive perception, positive motivation and coping (Sholeh 2005).

If someone is sincere and solemn in recitation, then Allah will be present to provide peace of mind so that the perception of stress will be positive and the stress response will be balanced. This is as Q.S. Surah Ar-Rad verse 28 explains that "only by remembering Allah, the heart calms down." The results of interviews with the intervention group found that changes in lifestyle, strict diet, self perception and society, as well as treatment and treatment processes can cause distress that makes stress perception becomes negative. Recitation and relaxation are therapeutic neurons that are able to optimize healthy and prosperous messages into an individual and are persuasive in providing peace of mind. Recitation and relaxation that are done well and istiqomah (consistency) can improve coping, cognition and improve the quality of life and accelerate recovery in people with diabetes mellitus.

The results of the interview found that around $86 \%$ of the participants said they were more comfortable and calm and were able to think positively when attending recitation and relaxation therapy. Recitation and relaxation as mind body therapy contain the belief that spiritual influences stress perception which has implications for physical and mental health. DhabbarMcEwen stated that stress perception is the result of learning processes to select, organize, and interpret stressors correctly. Perception of stress involves reason, experience, and emotion, so that the accuracy of perception of stress will produce accurate stress response (Putra 2011). Recitation and relaxation therapy is a combination of self-surrender training which is believed to be the highest strength in improving stress 
perception, generating a relaxation response, reducing symptoms of depression, so that it directly or indirectly influences blood sugar control (Asdie 2005). Recitation and prayer as psychoreligious therapy contain spiritual powers that increase self-confidence, a sense of optimism, influence the healing from diseases (Hawari 2005).

Recitation will improve spiritual health and remind that God's help is very close as Q.S. Al-Baqarah (2): 214 "Remember, Allah's help is very close." Recitation and relaxation are stimuli that have a positive impact on emotions so that by recitation the distress (unbalanced condition) may change into eustress (balanced condition). Spiritually guided perception is needed in adapting to the stress that comes with the complexity of diabetes mellitus management. Recitation and relaxation therapy that is done repeatedly (istiqomah) can produce energy to build adaptive and positive emotional coping, and improve the quality of life of people with diabetes mellitus.

\section{Recitation and relaxation reduce cortisol levels in type 2 diabetes mellitus patients with ADM}

The results showed that there were significant differences in the decrease in blood cortisol levels between control and intervention groups with $\mathrm{p}$ (0.024) <a (0.05). The intervention group experienced an increase in the mean value of cortisol levels from $13.526 \mu \mathrm{g} / \mathrm{dl}$ to $13.847 \mu \mathrm{g} / \mathrm{dl}$. The mean value of cortisol levels in the control group also showed higher increase than that in intervention group, namely from $10.447 \mu \mathrm{g} / \mathrm{dl}$ to 14.913 $\mu \mathrm{g} / \mathrm{dl}$.

Recitation in terminology is a human effort to get closer to God by remembering Him (Amin \& Al-Fandi 2008), which is able to reduce physiological responses to stress (Potter \& Perry 2009). Recitation as a main spiritual activity is a behavior that expresses a transcendental sense of connection with something greater than oneself (Rees 1987 in Asy'arie 2012). Recitation and relaxation done sincerely will have a holistic impact especially on improving stress perception and stress response.

Stress is defined as a non-specific response of the body to any demand (Hans Selye 1976 in Putra 2011). Stress is one of the factors that can activate the HPA Axis pathway to produce the hormone cortisol (Tortora \& Derrickson 2009, Silverthorn 2010, Sherwood 2011, Putra 2011), catecholamines, endorphins, encephalin and somatostatin (Setyawan 1995). Recitation and relaxation improve various emotional conditions. Emotional conditions, both positive and negative, can lead to HPA Axis activities which result in a tug between positive and negative attitudes. Stimulation to the parvocellular division of the praventicular nucleus (mpPVN) in the hypothalamus causes $\mathrm{CRH}$ secretion which affects Adrenocorticotropic Hormone (ACTH) activity. ACTH will stimulate the adrenal cortex to secrete cortisol (Purba in Putra, 2011).

This interesting condition between positive and negative attitudes also occurred in respondents in the intervention group. The results of open interviews and home visits found that most respondents were able to think positively (eustress) during recitation and relaxation. However, when returning home and the environment, distress reappears, the perception becomes negative again. If an individual is in a negative perception of stress, the HPA pathway will again secrete cortisol in response to stress. The less able an individual to adapt to stress, the more the increase of the cortisol level he would have, as stated in the concept of General Adaptation Syndrome (Selye 1976 in Tortora \& Derrickson 2009). General Adaptation Syndrome (GAS) states that stress will be responded biologically through the fightor-flight response, the resistance reaction, and the exhaustion stage (Potter \& Perry 2005, Tortora \& Derrickson 2009, Putra 2011, Nurdin 2014). Moreover, most respondents $(78.5 \%)$ were elderly people aged over 50 years. The condition of post power syndrome will affect the perception of stress, while physiologically the age above 50 years has entered the degenerative period. Miller (1999) explains that aging is caused by a decrease in the hypothalamus in the setting and is less sensitive in detecting hormone secretion. If the above factors are not well-regulated and balanced, then cortisol secretion increases and disrupts metabolic stability, neurohormonal working system and immune system of the body.

Selye (1976) has explained that prolonged exposure to high cortisol levels, especially in the third phase (exhaustion stage) stress, will cause energy waste in the muscles, suppression of the immune system, gastrointestinal ulceration, and beta (ß) cell failure of the pancreatic Langerhans island (Tortora \& Derrickson, 2009). Cortisol also enhances the process of gluconeogenesis, lipolysis, and proteolysis (Guyton \& Hall 2006, Smeltzer \& Bare 2008, Silverthorn 2010, Sherwood 2011), inhibiting the use of glucose by many tissues (except the brain) (Sherwood 2011). The effects of high cortisol levels work against insulin, inhibit peripheral tissue glucose utilization and increase insulin resistance by decreasing the translocation of glucose transporter 4 (GLUT 4) to the cell membrane (Nurdin 2014). This condition will make it difficult for the body's system to adapt to stress and will further increase cortisol levels and aggravate the condition of hyperglycemia in patients with type 2 diabetes mellitus. 
Recitation and relaxation are spiritual activities, which if done with good arrangement, focus, istiqomah and sincerity, will improve stress perception. A good perception of stress will have positive implications for the stress response mechanism through the HPA pathway so that there will be a balance in cortisol secretion. The balance of cortisol levels will reduce various adverse effects on the metabolism of carbohydrates, fats and proteins in type 2 diabetes mellitus patients with ADM.

\section{CONCLUSION}

Recitation and relaxation improve stress perception so that a balanced stress response in producing cortisol has an impact on the body's metabolic stability in patients with type 2 diabetes mellitus with ADM.

\section{REFERENCES}

Amin SM, Al-Fandi H (2008). Energi dzikir. Jakarta, Amzah, p 11

Asdie AH (2005). Patogenesis dan terapi diabetes mellitus tipe 2. Yogyakarta, MEDIKA, Fakultas Kedokteran Universitas Gadjah Mada

Asy'arie M (2012). Tuhan empirik dan kesehatan spiritual, editor Taufiq Pasiak, Centre For Neuroscience (C-NET). UIN Sunan Kalijaga. Yogyakarta.p. 131145

Ciechanowski PS, Katon WY, Russo JE (2000). Impact of depression on adherence, funcition, and cost. Arch Intern Medd 160, 3278-3285

Guyton AC, Hall JE (2008). Buku ajar fisiologi kedokteran. Alih bahasa: Irawati, et al. Ed. Rachman LY, et al. 11th ed. Jakarta, EGC, p 1187-1199

Hawari D (2005). Dimensi religi dalam praktek psikiatri dan psikologi. Jakarta, Faculty of Medicine-Universitas Indonesia, 5-8

Irawan D (2010). Prevalensi dan faktor risiko kejadian diabetes melitus tipe 2 di daerah urban Indonesia (Riskesdas Secondary Data Analysis in 2007). An unpublished thesis. Jakarta, Universitas Indonesia, 24

Khuwaja AK, Lalani S, Dhanani R, Azam IS, Rafique G, White F (2010). Anxiety and depression among outpatients with type 2 diabetes: A multi-centre study of prevalence and associated factors. Diebetology \& Metabolic Syndrome 2. Available from http://www. dmsjournal.com/ content/ 2/1/72

Kumar V, Abbas KA \& Aster JC (2013). Robbins basic pathologic. 9th ed. Canada, Elsevier Saunders, p 739744
Lorentz M (2006). Stress and psychoneuroimmunology revisited: Using mind body interventions to reduce stress. Alternative Journal of Nursing. Edition 11, 111

Miller CA (1999). Nursing care of older adults: theory and practice. Philadepia, Lippincott

Ministry of Health of Republic of Indonesia (2014). Infodatin pusat data dan informasi Kementrian Kesehatan R.I: Situasi dan analisis diabetes. Jakarta, p 1-6

Nurdin AE (2014). Psikoneuroimunologi dasar. 5th ed. Padang, Universitas Andalas, p 148, 157

Nursalam (2007). Asuhan keperawatan pada pasien terinfeksi HIV. Jakarta, Salemba Medika, p 33

Potter AP, Perry GA (2009). Buku ajar fundamental keperawatan konsep proses dan praktik. 4th ed. Jakarta, Buku Kedokteran EGC, p 267-277, 476-477, 564-573

Putra ST (2011). Psikoneuroimunologi Kedokteran. 2nd ed. Surabaya, Airlangga University Press, p 5-8, 2425, 30-36

Selye H (1936). A syndrome produced by diverse nocuous agents. Nature 138

Setyawan S (1995). Pengaruh latihan fisik aerobik dan anaerobik terhadap pola respon ketahanan tubuh. An unpublished dissertation. Surabaya, PPS Unair

Sherwood L (2011). Human physiology: From cell to systems. 7th ed. USA, Brooks/Cole Cengage Learning, p 675, 700-712

Sholeh M (2005). Tahajud manfaat praktis ditinjau dari ilmu kedokteran. Yogyakarta, Forum Studi Himanda, p 10-14, 24-26, 31, 33-36

Silverthorn DU (2010). Human physiology an integrated approach. 5th ed. San Francisco, Pearson Benjamin Cummings, p 760

Smeltzer SC, Bare BG (2009). Buku ajar keperawatan medical bedah Brunnert \& Suddarth. 8th ed. Jakarta, Penerbit Buku Kedokteran: EGC, p 1280

Soegondo S (2009). Prinsip penanganan diabetes, insulin dan obat oral hipoglikemik oral, dalam Soegondo S, Soewondo P, \& Subekti I. Ed. Penatalaksanaan diabetes melitus terpadu. Jakarta, FKUI, p 111-133

Tortora GJ, Derrickson B (2009). Principles of anatomy and physiology. 12th ed. USA, John Wiley \& Sons, Inc, p $675-676$

Yanti N (2012). Perbandingan efektifitas terapi dzikir dengan relaksasi benson terhadap kadar glukosa darah pasien diabetes mellitus di Sumatra Barat. An unpublished thesis. Jakarta, Universitas Indonesia, p $60-72$ 